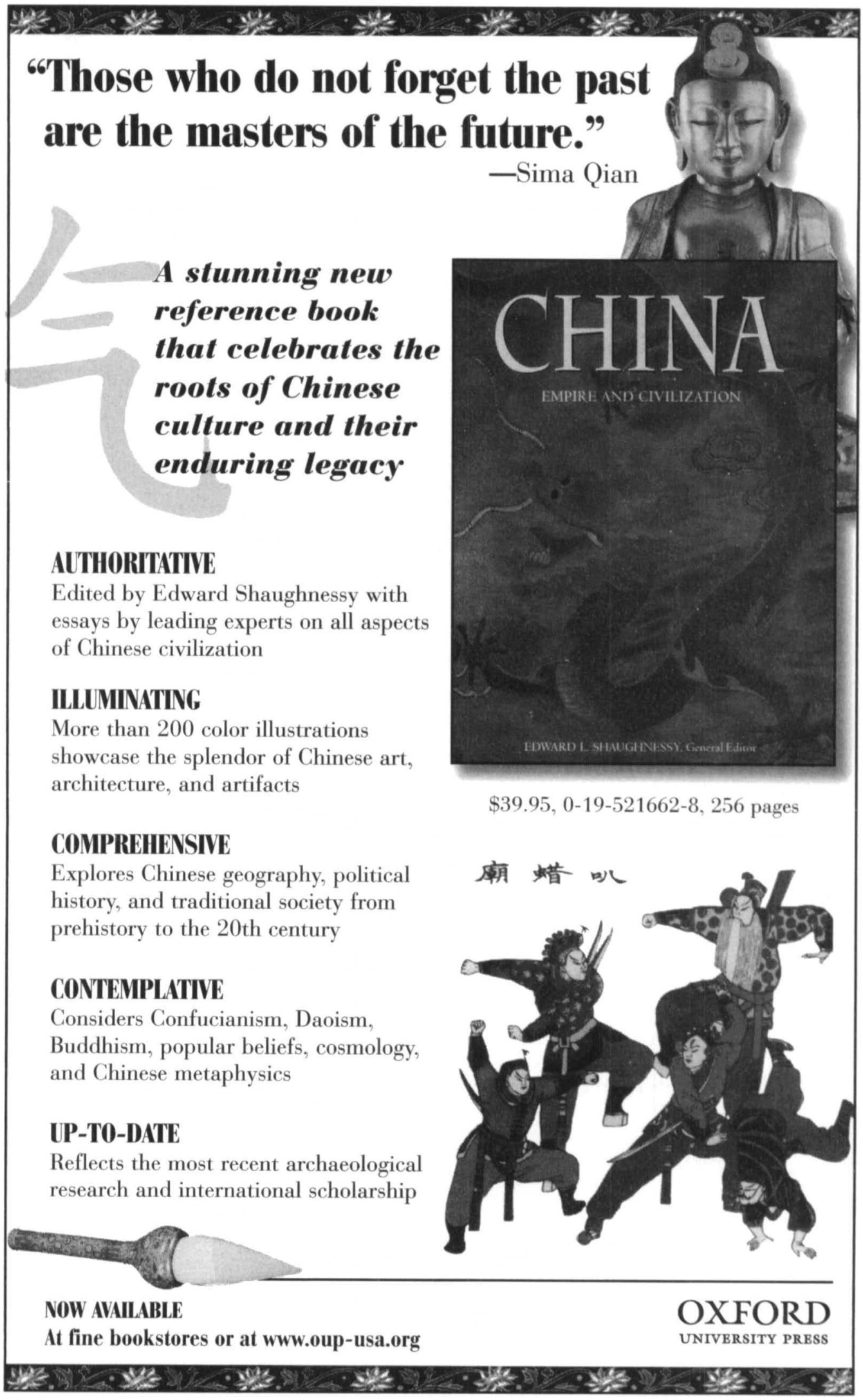




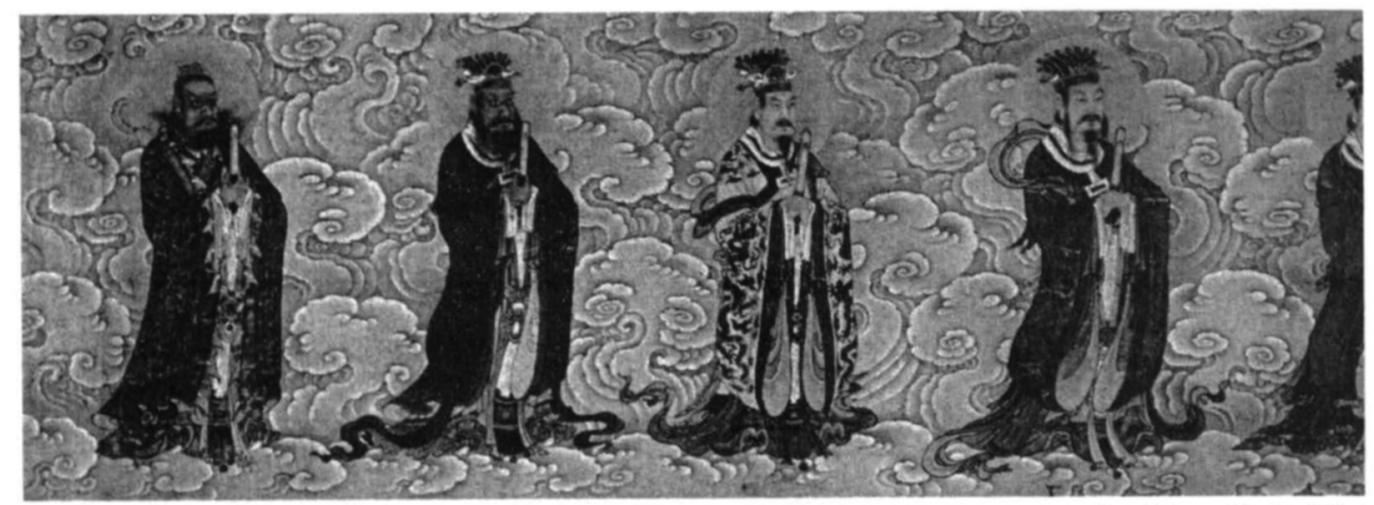

From Tooism and the Arts of China

Taoism and the Arts of China

Stephen Little

With essays by Kristofer Shipper, Wu Hung, Patricia Ebrey, and Nancy Steinhardt

Taoism and the Arts of China brings together a remarkable collection of art from one of China's most ancient and influential traditions. This opulent book includes more than 150 works of art from as early as the late Zhou dynasty (fifth-third century b.c.) to the Qing dynasty (1644-1911). Many of these works are paintings that show the breathtaking range of style and subject that makes the Taoist heritage so rich. Sculpture, calligraphy, rare books, textiles, and ritual objects are also represented. This volume affords a sweeping view of an artistic terrain that until now has received too little exposure in the West. Its publication constitutes a major advance in Western understanding of this important tradition.

Copublished with the Art Institute of Chicago $\$ 60.00$ hardcover, $\$ 39.95$ paperback

\section{The Life of Buddhism}

Frank E. Reynolds and Jason A. Carbine, Editors

"Whereas traditional scholarship has focused on voices of elite groups, philosophies of different sects, and textual ideals, The Life of Buddhism presents a wide range of Buddhist practice in relatively contemporary contexts. The book represents a step forward by emphasizing the iconography, individualized and communal rituals, in addition to diverse practices and devotional expressions of both monastic and lay communities, and will make a significant contribution to the field of both religious studies and Buddhist studies."

-Bernard Faure, author of The Red Thread: $\$ 45.00$ hardcover, $\$ 17.95$ paperback Buddhist Approaches to Sexuality

\section{Who Are the Jews of India?}

Nathan Katz

"Who Are the lews of India? is the first book to present a readable, interesting, integrated treatment of the three distinct Indian Jewish communities that have evolved-the Cochin Jews, the Bene Israel, and the Baghdadis. It also brings together material on the Baghdadi communities of Bombay, Calcutta, and Southeast Asia in a way that I have never seen before. Its presence is most welcome; its scholarship is superior."

-Daniel Gold, author of Comprehending the Guru: Toward $\$ 45.00$ hardcover

\section{IN PAPERBACK}

\section{Behind Mud Walls}

Seventy-five Years in a North Indian Village William Wiser and Charlotte Wiser With new chapters by Susan S. Wadley Foreword by David G. Mandelbaum UPDATED AND EXPANDED EDITION

"Behind Mud Walls is an excellent introduction to the changes that have taken place in India from the mid-1920s to today, seen from the village level. It introduces the changing world of the village, where still 50 percent of the world's population, and 75 percent of India's population, live."

- Howard Spadek, author of The World's History

At bookstores or order (800) 822-6657 


\section{Re-Drawing Boundaries}

Work, Household, and Gender in China Barbara Entwisle and Gail E. Henderson, Editors

Representing the culmination of more than a decade of empirical research in post-Mao China, this collection of essays explores changes in the nature of work in relation to changes in households, migration patterns, and gender roles during an era of economic reform. The contributors are respected scholars in fields that range from history and anthropology to demography and sociology. \$50.00 hardcover, $\$ 19.95$ paperback

\section{In One's Own Shadow}

An Ethnographic Account of the Condition of Post-reform Rural China

\section{Xin Liu}

"This study of a Shaanxi village offers a rare glimpse of the everyday politics and gritty struggles in interior Chinese communities, where despite a booming national economy there is still not enough to go around. Xin Liu has given us an unflinching yet sympathetic view of people trapped in a broad national transformation that is not of their own making. The characters and strategies that emerge from this study are important,

troubling, unforgettable." - Judith Farquhar, author of Knowing Practice: The Clinical Encounter of Chinese Medicine $\$ 45.00$ hardcover, $\$ 15.95$ paperback

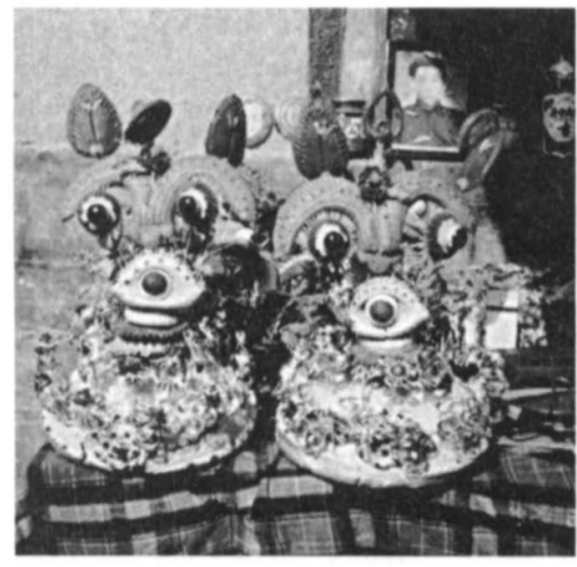

From in Ones Own Shadow

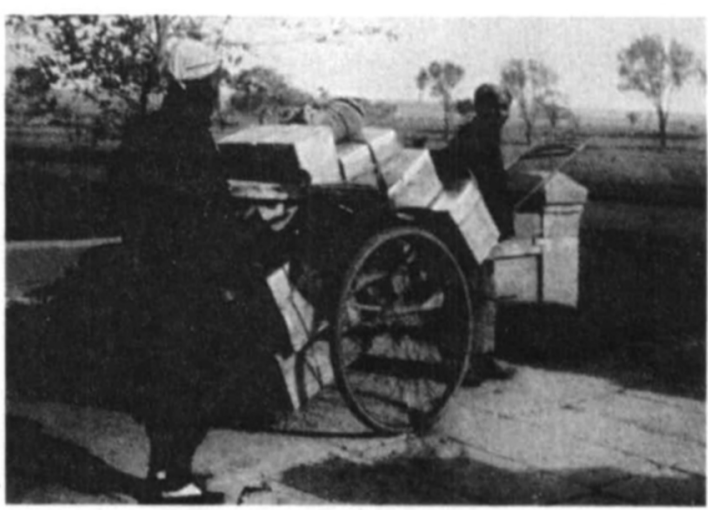

From Encountering Chinese Networks

\section{Encountering Chinese Networks}

Western, Japanese, and Chinese Corporations

in China, 1880-1937

Sherman Cochran

Big businesses have faced a persistent dilemma in

China since the nineteenth century: how to retain control over corporate hierarchies while adapting to local social networks. Cochran, in the first study to compare Western, Japanese, and Chinese businesses in Chinese history, shows how various businesses have struggled with this issue as they have adjusted to dramatic changes in Chinese society, politics, and foreign affairs. $\$ 40.00$ hardcover

\section{The Manchurian Myth}

Nationalism, Resistance, and Collaboration in Modern China Rana Mitter

A powerful element in twentieth-century Chinese politics has been the myth of Chinese resistance to Japan's seizure of Manchuria in 1931. Investigating the shifting alliances of key players in that event, Mitter traces the development of the narrative of resistance to the occupation and shows how it became part of China's political consciousness, enduring even today. $\$ 45.00$ hardcover

\section{Peking}

Temples and City Life, 1400-1900

Susan Naquin

Using the city's temples as her point of entry, Naquin carefully excavates Peking's varied public arenas, the city's transformation over five centuries, its human engagements, and its rich cultural imprint. This study shows how modern Beijing's glittering image as China's great and ancient capital came into being and reveals the shifting identities of a much more complex past. \$80.00 hardcover

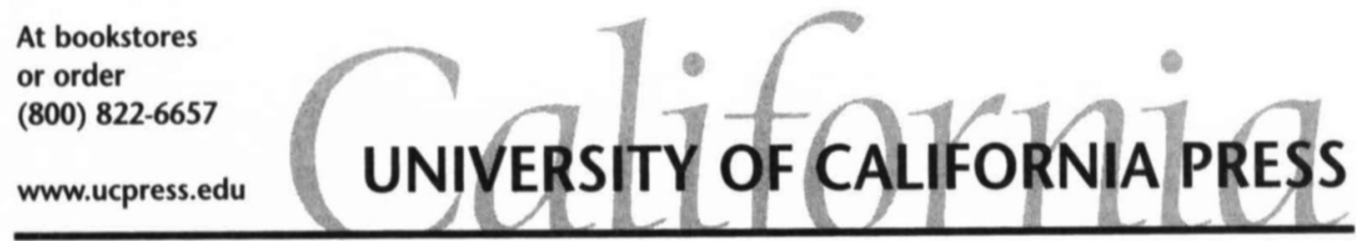




\section{New in Asian Studies}

\section{Hanoi}

Biography of a City

WILLIAM S. LOGAN

For more than a thousand years, Hanoi has been bending with the wind to resist foreign

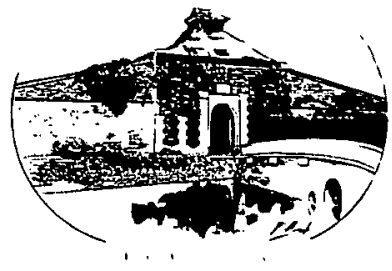
domination while absorbing foreign influences. Today it teems with competing heritages-it is at once a museum of socialist moments, a masterpiece of French colonial urbanism, and the home of ancient Buddhist temples. William Logan explores the many layers of Hanoi's built environment, from ancient times until the present.

Clothbound, $\$ 40.00$

\section{The Origins of the Chosŏn Dynasty}

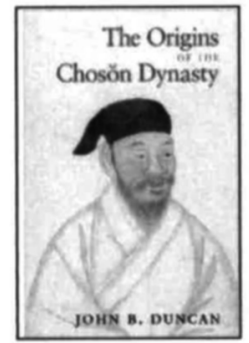

\section{JOHN B. DUNCAN}

Drawing on a wealth of data compiled from primary sources, this landmark study shows that a key feature of the establishment of the Choson dynasty (1392-1910) was continuity in the structure and composition of the central ruling class and argues that the main force behind the establishment of the Choson was the need to revamp institutions to protect aristocratic interests.

Korean Studies of the Henry M. Jackson School of International Studies Clothbound, $\$ 60.00$

\section{Manchus and Han}

Ethnic Relations and Political Power

in late Qing and Early Republican China, 1861-1928

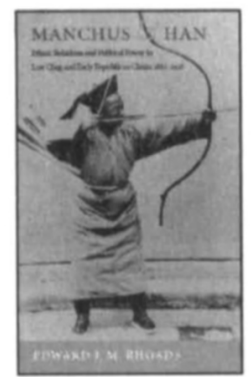

EDWARD J.M. RHOADS

A pathbreaking study that will change the way historians of China view the events leading to the fall of the Qing dynasty. Likewise, it will clarify for ethnologists the unique origin of the Manchus as an occupational caste and their shifting relationship with the Han, from border people to rulers to ruled.

Studies in Ethnic Groups in China

Clothbound, $\$ 55.00$

Available from your bookstore or call 1-800-441-4115

\section{UNIVERSITY OF WASHINGTON PRESS}

P.O. Box 50096 Seattle, WA 98745-5096

\section{*utur.zashington.edu/laupuess/}




\title{
Beyond Turk and Hindu
}

\author{
Rethinking Religious Identities in Islamicate South Asia \\ Edited by David Gilmartin and Bruce B. Lawrence
}

\begin{abstract}
"[Sets] the stage for a rewriting of nearly one-thousand years of history to create new understandings of the nature of cultural encounters. ... The volume breaks free from the polemics of present-day politics and historicist distortions that have seeped into most standard texts."-David Lelyveld, Cornell University

Order through full-service booksellers, through our website at www.upf.com or

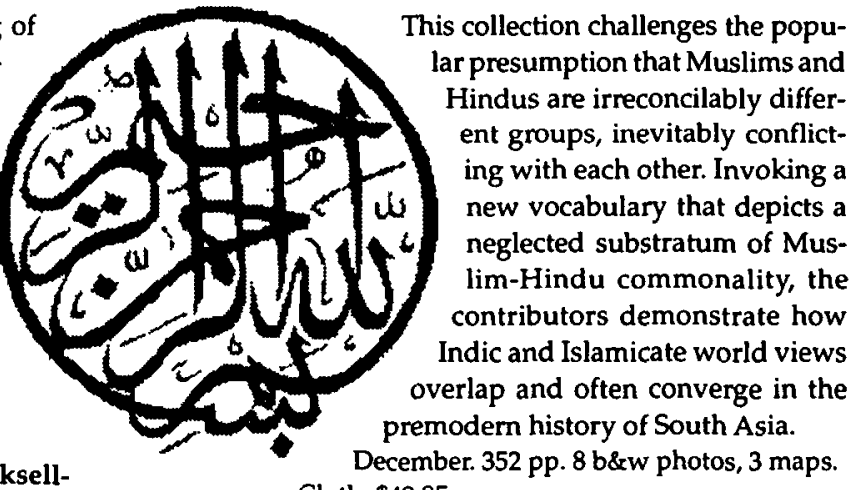
Cloth, $\$ 49.95$

toll free: 1-800-226-3822 with VISA or M/C.

GAINESVILLE TALLAHASSEE TAMPA BOCA RATON PENSACOLA ORLANDO MIAMI JACKSONVILLE FORT MYERS
\end{abstract}
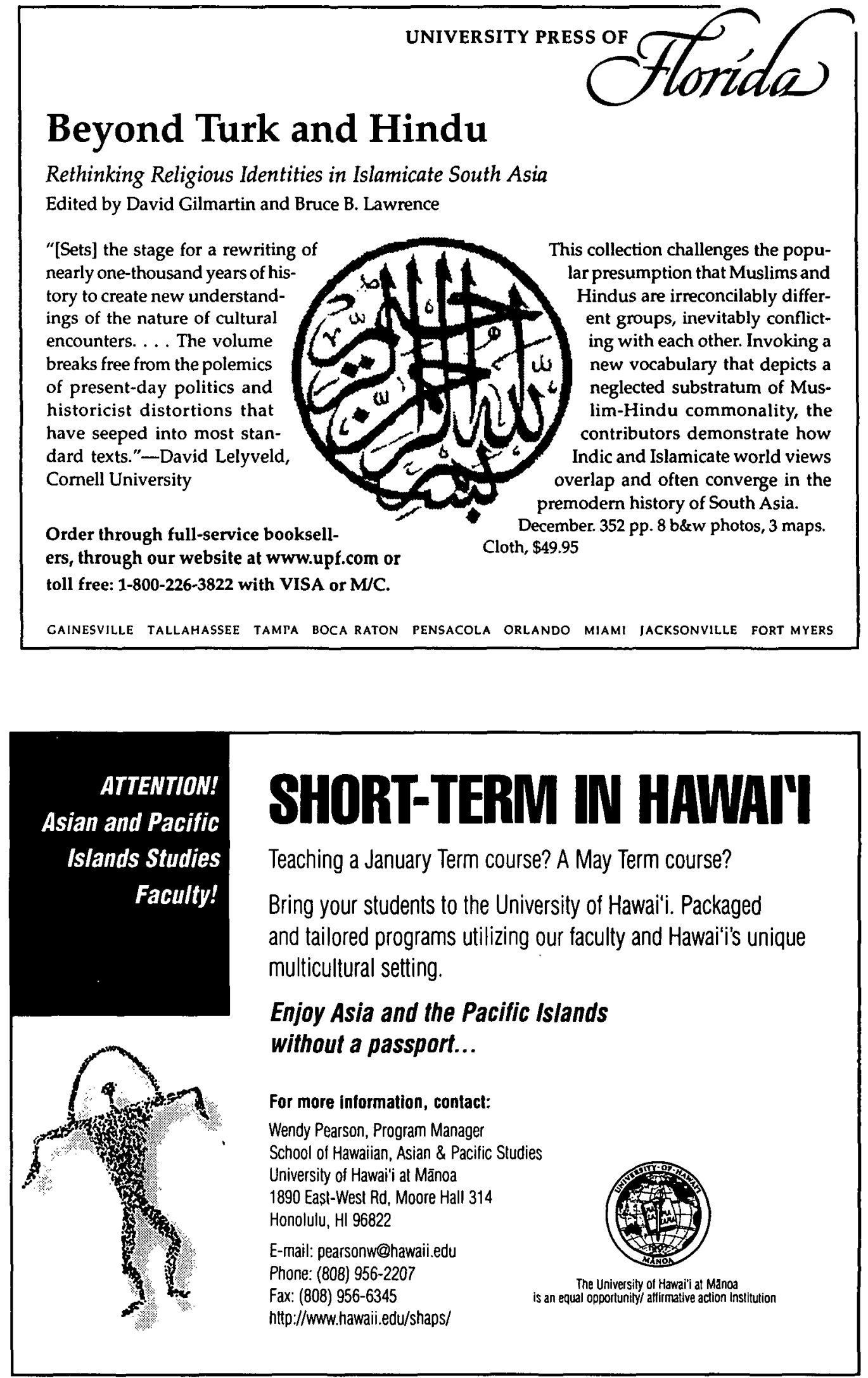


\section{Inside Asia}

\section{Economic and Social Survey of Asia and the Pacific 2000}

This edition of the Economic and Social Survey of Asia and the Pacific reviews the progress made by the ESCAP

(Economic and Social Commission for Asia and the Pacific) region over the past year, assesses the policy initiatives that have been taken and identifies a number of areas for further action by policy-makers. The publication also examines the international financial system, focusing on ideas for reform in the light of the financial crisis of 1997-1998.

E.00.II.F.19 $\quad 9211199557 \quad 266 \mathrm{pp} \quad \$ 55.00$

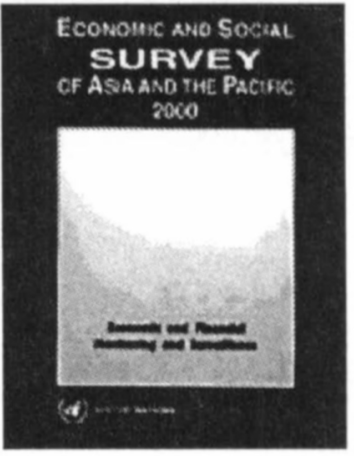

\section{Statistics on Women in Asia and the Pacific}

This publication demonstrates how women have participated and contributed to the changes in the social and economic conditions of the region. Using multiple-year statistics on women and men, a comparative assessment of the status of women can be made. In addition, the publication presents tables on special topics, provides a consistent set of demographic estimates and projections.
E.00.II.F.10
9211199573
282pp.
$\$ 25.00$

\section{Asia's Emerging Regional Order: Reconciling Traditional and Human Security}

This book explores alternative approaches to human security, a concept especially relevant to the Asia-Pacific region which is experiencing immense structural changes. The publication presents a diverse and stimulating series of essays written by analysts to help understand how human security policies relate to the dynamics of the contemporary international environment.
E.00.III.A.3
9280810464
$352 \mathrm{pp}$.
$\$ 29.95$

\section{Interrelationship Between Trade and Environment in Asia and the Pacific}

The interrelationship between trade and environment has been debated in various international forums. In the Asia-Pacific region, international trade has proven to be an engine of growth, creating the need for policies on environment and trade to be mutually supportive. This publication gives an introduction to global developments on the subject and presents a regional overview.
E.00.II.F.38
9211199867
248pp.
$\$ 35.00$

\section{United Nations Publications}

Sales and Marketing Section, Room DC2-0853, Dept.A168, New York, N.Y. 10017.

Tel. (800) 253-9646, (212) 963-8302 Fax. (212) 963-3489.

Visa, MC and AMEX accepted. Domestic orders: Add $5 \%$ of gross

( $\$ 5.00$ minimum) for shipping and handling. Overseas Orders: Add US $\$ 5.00$ per title in addition to US $\$ .00$ basic handling charge.

\section{E-Mail: publications@un.org Internet: lıttp://www.un.org/publications}




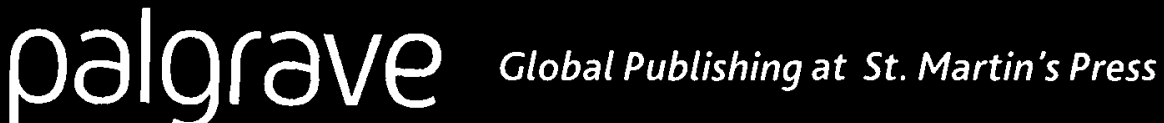

Palgrave is the new publishing imprint at St. Martin's Press that combines the Scholarly and Reference Division with Macmillan Press (UK). Our goal is to be the new academic publisher of choice. For more information visit us at www.palgrave.com.

\section{NOW IN PAPERBACK! \\ KASHMIR IN CONFLICT \\ Victoria Schofield}

As India and Pakistan square up for conflict with possible nuclear consequences, Kashmir is once again in center stage. This book examines the Kashmir conflict in its historical context, from the period when the valley was an independent kingdom up to the struggles of the present day.

$2000 / 256$ pp.

1-86064-545-3 / \$18.95 paperback I.8.Tauris

\section{KOREAN CRISIS}

Unraveling of the Miracle in the IMF Era

\section{Donald Kirk}

"Donald Kirk is a veteran observer of the Korean scene. He has a talent for blending politics, economics, and culture into a lively story that those interested in the heroic as well as tawdry sides of the ongoing Korean 'miracle' won't want to miss."

$$
\begin{array}{r}
\text {-William Stueck, author of } \\
\text { The Korean War: } \\
\text { An International History }
\end{array}
$$
$2000 / 400$ pp.

0-312-22442-7 / \$55.00 hardcover

\section{CHINA AND THE PEOPLE'S LIBERATION ARMY}

Great Power or Struggling Developing State?

\section{Solomon Karmel}

This book employs extensive research of Chinese and foreign sources to understand shortcomings in the strategic, military, and industrial overhaul of China's military-industrial complex. $2000 / 240$ pp.

0-312-22389-7 / \$49.95 hardcover
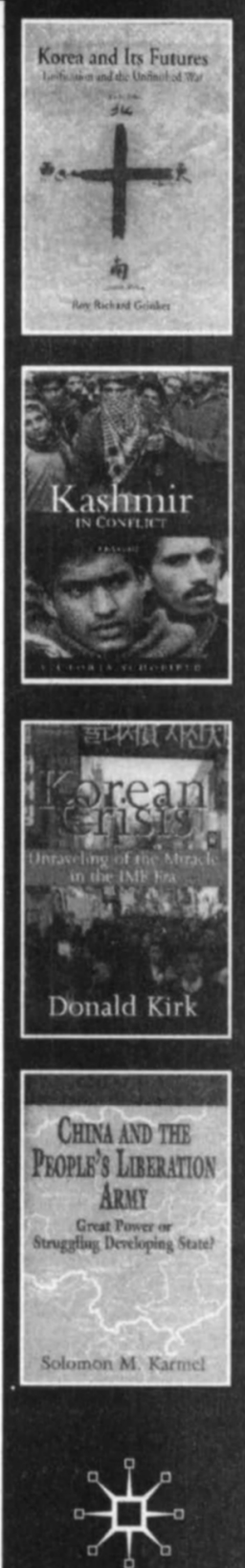

\section{HONG KONG THE} SUPER PARADOX

Life After Return to China

Edited by James $C$. Hsiung

This book cuts into the cold reality of post-colonial Hong Kong, which demonstrates paradoxical outcomes to pre-1997 prophecies. Hong Kong the Super Paradox offers plausible reasons for this wide discrepancy between expectations and outcome.

$2000 / 368$ pp.

0-312-22293-9 / \$55.00 hardcover

\section{THE CASPIAN REGION AT}

\section{A CROSSROAD}

Challenges of a New Frontier of Energy and Development

Edited by Hooshang Amirahmadi The Caspian Region emerged as a new frontier of energy and development after the collapse of the Soviet Union. However, a very lopsided understanding of the region has emerged. This book attempts to correct this deficiency with essays by recognized experts in the region. $2000 / 320$ pp.

$0-312-22351-x / \$ 55.00$ hardcover

NOW IN PAPERBACK!

\section{KOREA AND ITS FUTURES}

Unification and the Unfinished War Roy Richard Grinker

"A provocative sociocultural study ..." - Library Journal

This book suggests that a fundamental obstacle to peace on the peninsula is that South Korea has become a nation in which nearly all aspects of economic, political, and cultural identity are defined in opposition to North Korea. $2000 / 336$ pp.

0-312-22472-9 / \$18.95 paperback

\section{Fifth Avenue New York, NY 10010}




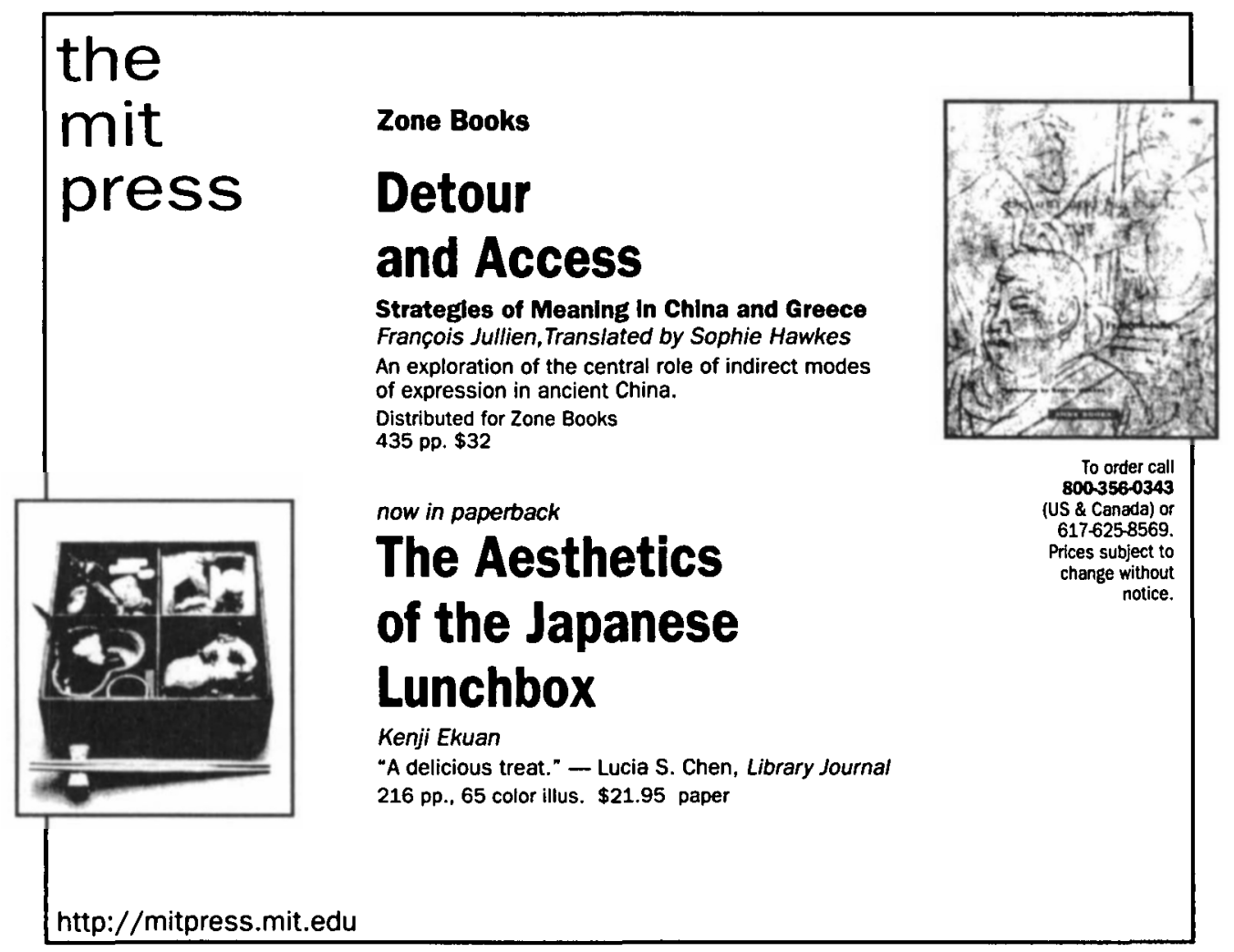

\section{Think Routledge for Asian Studies}
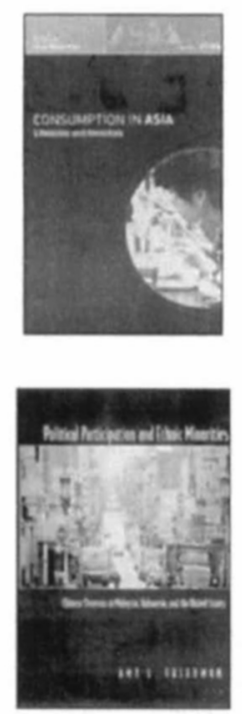

Reform and Recovery in East Asia

The Role of the State and Economic Enterprise

Edited by Peter Drysdale

This exciting collection offers a completely up-to-date assessment of the progress of East Asian recovery and provides a detailed review of the region's economies. $\$ 29.95 / \mathrm{pb}$

Consumption in Asia Lifestyles and Identities Edited by Chua Beng Huat These essays give the first detailed analysis of consumerism within East and South-East Asia and contain case studies from Malaysia, Hong Kong. Indonesia, Singapore and Japan. 529.99/pb
Political Participation and Ethnic Minorities Chinese Overseas in Malaysia, Indonesia, and the United States Amy L. Freedman

From New York City's Chinatown to urban Indonesia, there are fifty-five million ethnic Chinese living outside of China. This empirical study examines the hows and whys of Chinese overseas political activity in three diverse countries.

$524.99 / \mathrm{pb}$

Asian Nationalism Edited by Michael Leifer Bringing together internationally renowned experts in the field, this collection analyzes current theories of nationalism and features detailed case studies on China, Japan, Tahwan, India, Indonesia and the Philippines. \$29.99/pb 


\section{Remembering ...}

The 50th Anniversary of the Outbreak of the Korean War The 25th Anniversary of the End of the Vietnam War The 20th Anniversary of the Kwangju Uprising

\section{REMEMBERING THE} "FORGOTTEN WAR"

The Korean War Through Literature and Art

Philip West, Suh Ji-Moon

256 pages $0-7656-0696-8$ Cloth $\$ 65.00$

\section{WAR AND DEMOCRACY}

A Comparative Study of the Korean War and the Peloponnesian War David R. McCann, Barry S. Strauss 388 pages $0-7656-0694-1$ Cloth $\$ 77.95$

\section{MY VERY LAST POSSESSION}

And Other Stories by Pax Wanso Translated by Chun Kyung-Ja

240 pages $0-7656-0428-0$ Cloth $\$ 45.00$ 0-7656-0429-9 Paper $\$ 22.95$

\section{THE VIETNAMESE WAR}

Revolution and Social Change in the Mekong Delta

David Elliott

Two-volume Set

1200 pages $0-7656-0602-X$ Cloth $\$ 140.00$

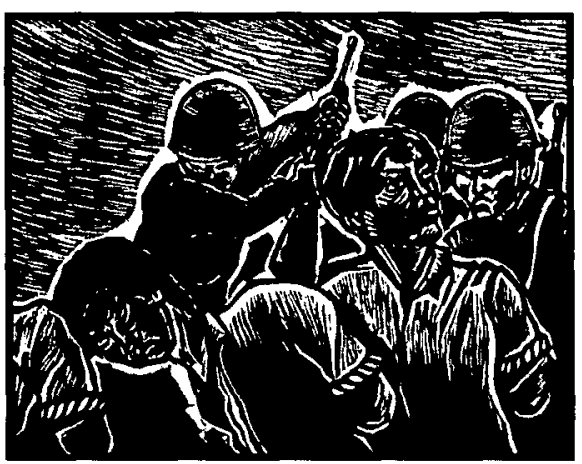

\section{THE KWANGIU UPRISING}

Eyewitness Press Accounts of Korea's Tiananmen

Henry Scott-Stokes, Lee Jai Eui Foreword by President Kim Dae Jung 268 pages $0-7656-0636-4$ Cloth $\$ 37.50$ 0-7656-0637-2 Paper \$18.95

\section{Congratulations to ...}

Lynn T. White III for winning the Association for Asian Studies 2000 Levenson Prize for the Best Book on Twentieth Century China and receiving a Choice Outstanding Academic Book award for

\section{UNSTATELY POWER}

Vol. I: Local Causes of China's Economic Reforms 544 pages 0-7656-0044-7 Cloth $\$ 70.95 / 0045-5$ Paper $\$ 26.50$

\section{and to ...}

Yok-shiu Lee and Alvin Y. So, editors., for winning the 2000 Harold and Margaret Sprout Award, given by the International Studies Association, for the best book published on international environmental affairs during the previous two years for

\section{ASIA'S ENVIRONMENTAL MOVEMENTS}

Comparative Perspectives

328 pages 1-56324-908-1 Cloth $\$ 77.95 / 909-X$ Paper $\$ 27.95$ 


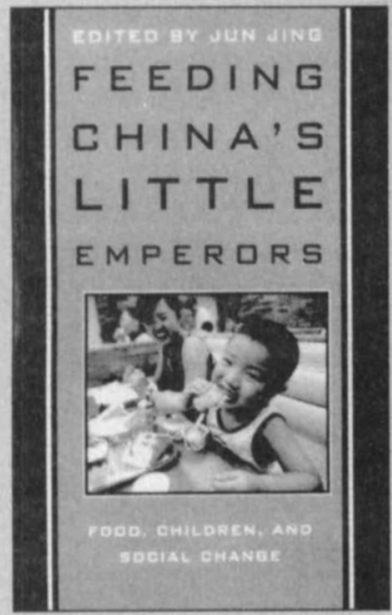

Feeding China's

Little Emperors

Food, Children, and Social Change

Edited by JUN JING

This book focuses on how the transformation of the food habits of Chinese children-involving snack foods, soft drinks, and fast foods from such Western outlets as McDonald's and Kentucky

Fried Chicken-has changed the intimate relationship of childhood, parenthood, and family life.

$\$ 17.95$ paper $\$ 49.50$ cloth

\section{The Practices of Painting}

in Japan, 1475-1500

QUITMAN EUGENE PHILLIPS

This book attempts to expand the grounds and methodology of studying Japanese art history by focusing on the conditions, procedures, events, and social interplay that characterized the production of paintings in late-15th-century Japan. Though the book's ultimate concerns are art historical, its analysis also draws from the insights of sociology and social history.

$\$ 49.50$ cloth

\section{The Price of Death}

The Funeral Industry in Contemporary Japan

HIKARU SUZUKI

"This original and stimulating book presents detailed ethnographic information on a little-known aspect of Japanese society, It is a lively and moving account, with many interesting analytic points. The author's behindthe-scenes perspective on the funeral industry and the symbols and social markers involved in their performance of the funeral are fascinating."

\section{-Theodore Bestor, Cornell University}

$\$ 35.00$ cloth

\section{Song in an Age of Discord}

The Journal of Sōchō and Poetic Life in Late Medieval Japan

\section{H. MACK HORTON}

This is a companion volume to the author's translation of Saiokuken Sōchō's The Journal Of Sôchō (Stanford, 1998). The volume gives an overview of the author's life and times, explores the relationships between politicians, patronage, and the creative process, and reads the journal in terms of the standard norms of genres that Sōchō appropriated and reinterpreted.

$\$ 60.00$ cloth

\section{Between Mecca} and Beijing

Modernization and Consumption Among Urban Chinese Muslims MARIS BOYD GILLETTE

"For Muslims in China, eating is a political act, and this book, the most detailed and comprehensive study of a Muslim community in China to date, explains why, In a society that views pork and secularism as the norm, to be a Muslim can be a challenging if not impossible endeavor. The book shows how a small minority can survive and maintain its values in the face of frequent intolerance by the dominant culture." - Dru C. Gladney, University of Hawaii $\$ 45.00$ cloth

\section{The Journal of Sōchō}

\section{Translated and \\ Annotated by \\ H. MACK HORTON}

The author, Saiokuken Sōchō (1448-1532) - the preeminent linked-verse (renga) poet of his time-provides in his journal a vivid portrayal of cultural life in the capital and the provinces, together with descriptions of battles and great warrior families, the dangers of travel through war-torn countryside, and the plight of the poor. $\$ 24.95$ paper $\$ 60.00$ cloth 


\section{Cadres and Corruption \\ The Organizational \\ Involution \\ of the Chinese \\ Communist Party \\ XIAOBOLU}

"In a nuanced, informative, and analytically sophisticated fashion, this book traces present-day corruption in China back historically to institutional frameworks that the Communist Party put in place prior to its rise to power. In a fascinating narrative, the author shows the mutation of these institutions and of officials' behavior over the succeeding decades." -Jonathan Unger, Australian National University

$\$ 55.00$ cloth

\section{Dreaming of Gold, Dreaming of Home Transnationalism and Migration Between the United States and South China, 1882-1943 \\ MADELINE Y. HSU}

This book studies transnationalism among immigrants from the county of Taishan, from which, until 1965 , a high percentage of the Chinese in the United States originated. It tells in great detail of the continuing ties between Taishanese remaining in China and their kinsmen seeking their fortune in "Gold Mountain," long after the gold in California ran out.

$\$ 45.00$ cloth
NOW IN PAPERBACK

Sun Yat-sen

MARIE-CLAIRE BERGÉRE

Translated by

Janet Lloyd

Arguing that the life and work of Sun Yat-sen have been distorted by both myth and demythification, the author provides a fresh overall evaluation of the man and the events that turned an adventurer into the founder of the Chinese Republic and the leader of a great nationalist movement.

$\$ 24.95$ paper $\$ 51.00$ cloth

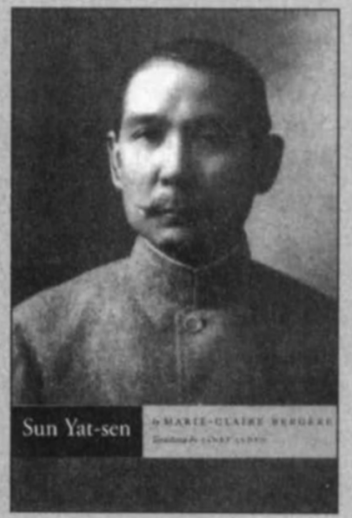

\section{The Annals of Lü Buwei}

Translated by

JOHN KNOBLOCK AND

JEFFREY RIEGEL

This is the first complete English translation of Liishichungiu, complied in 239 B.C. An exceptionally rich and comprehensive com pendium, The Annals recounts in engaging, straightforward, and readable prose the great variety of beliefs and customs of the time in an attempt to encompass the world's knowledge in one encyclopedia.

$\$ 75.00$ cloth

\section{Chinese Magical Medicine}

MICHEL STRICKMANN

Edited by Bernard Faure

"Strickmann unearths the history, literature, and fundamental assumptions of Buddhist and Taoist religious rituals and offers a wealth of astute social and literary commentary. He combines the highest standards of philological and historical scholarship with an eye for the spiritually bizarre, the socially telling, and the psychologically gripping detailall in a style that is elegant, entertaining, well-organized, and always accessible."

- Stephen F. Teiser, Princeton University

$\$ 24.95$ paper $\$ 65.00$ cloth

\section{A Chinese Literary Mind \\ Culture, Creativity, and Rhetoric \\ in Wenxin diaolong}

\section{Edited by ZONG-QI CAI}

This is the first book-length study in English of Wenxin diaolong by Liu Xie (ca. 465-ca. 521), arguably the most complex and comprehensive work of literary criticism in ancient China. For centuries it has intrigued and inspired Chinese literati, and modern English-speaking scholars have also found it an important source for the study of traditional Chinese poetics and aesthetics. $\$ 55.00$ cloth 
NEIW EROM

\section{BROOKINGS INSTITUTION PRESS}
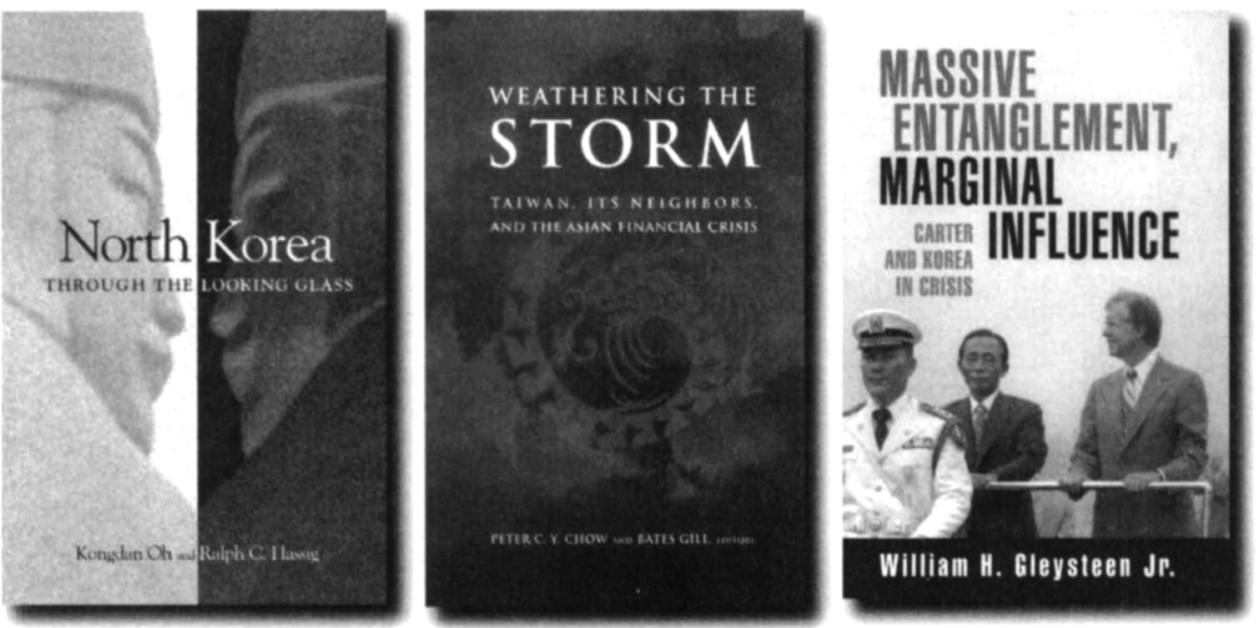

North Korea through the Looking Glass

Kongdan Oh and Ralph C. Hassig cloth, 0-8157-6436-7, \$39.95

paper, 0-8157-6435-9, \$16.95

Explores what the leadership and masses believe about their current predicament and offers policy suggestions to deal with this anachronistic regime.

Weathering the Storm Taiwan, Its Neighbors, and the Asian Financial Crisis

Peter C.Y. Chow and Bates Gill, eds. paper, 0-8157-1399-1, \$19.95

Provides much-needed new understanding and reasoned policy lessons to help the Asia-Pacific region meet its vast economic potential.

Order from the

Brookings Institution Press

Phone: 800-275-1447 or 202-797-6258

Fax: 202-797-2960

Email: BIBOOKS@brookings.edu
Coming Soon in Paperback

Massive Entanglement, Marginal Influence Carter and Korea in Crisis William H. Gleysteen Jr. paper, 0-8157-3169-8, \$17.95

Examines how Carter's troop withdrawal and human rights policies contributed to the demise of Korean President Park Chung Hee.

\section{NEW FROM THE ASIA FOUNDATION}

America's Role in Asia American Views paper, 1-892325-02-0, \$10.95

America's Role in Asia Asian Views

paper, 1-892325-03-9, \$10.95

These companion volumes analyze key problems in U.S.-Asian relations and offer policy recommendations. 


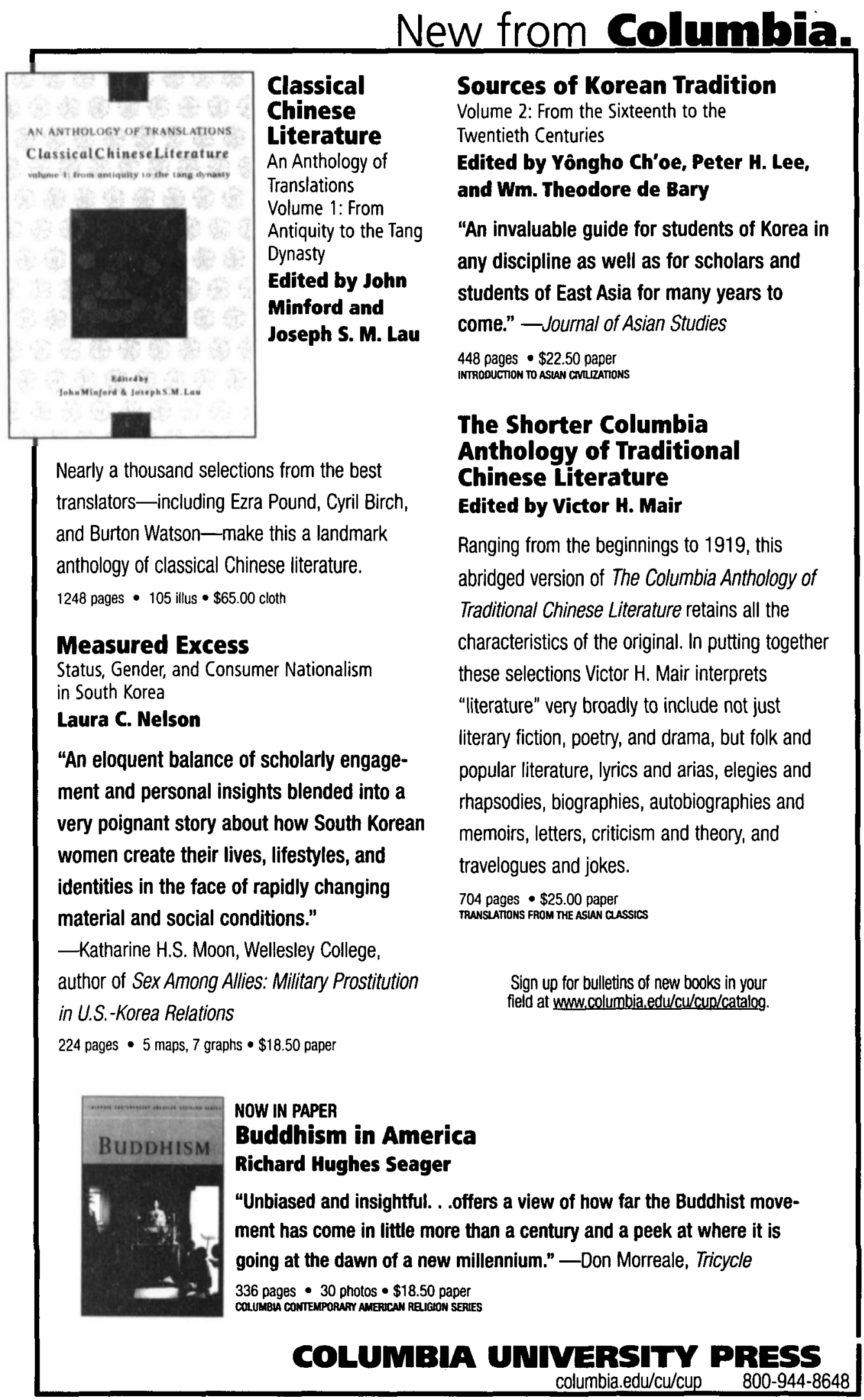




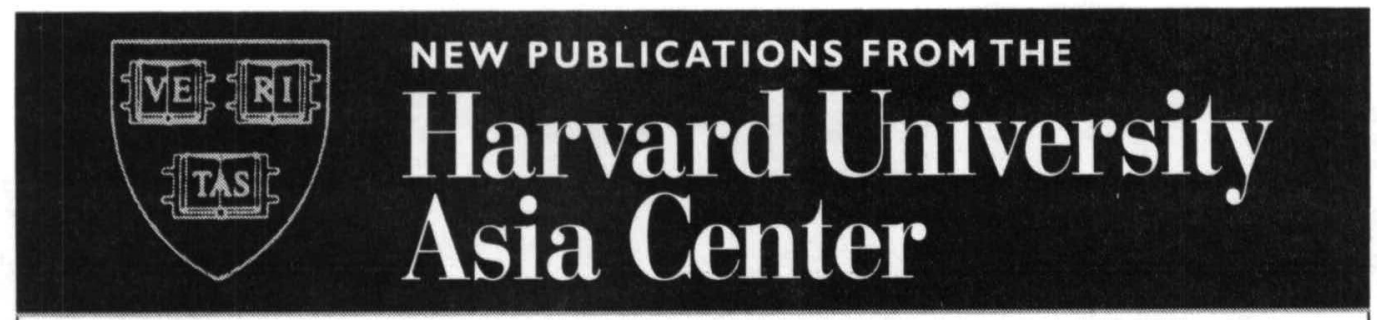

\section{JEWEL IN THE ASHES}

Buddha Relics and Power in

Early Medieval Japan

\section{BRIAN D, RUPPERT}

This study addresses the relationship between the veneration of Buddha relics and the appropriation of power in Japan from the ninth to the fourteenth centuries and analyzes the ways in which relics were used in interactions among the clergy, the imperial family, aristocrats, and warriors. $\$ 49.50$ doth. 2 tables, 10 figs. 525 pp.

\section{CONSTRUCTING "KOREAN" ORIGINS}

A Critical Review of Archaeology,

Historiography, and Racial Myth in Korean

State-Formation Theories

\section{HYUNC IL PAI}

In this wide-ranging study, Pai examines how archaeological finds from throughout Northeast Asia have been used in Korea to construct a myth of state formation emphasizing the ancient development of a pure Korean race that created a civilization rivaling those of China and Japan. $\$ 49.50$ cloth. 7 maps, 27 figs. $575 p p$.

\section{EVIL AND/OR/AS THE GOOD}

Omnicentrism, Intersubjectivity, and Value Paradox in Tiantai Buddhist Thought

\section{BROOK ZIPORYN}

"Other than the devil there is no Buddha; other than the Buddha there is no devil." An exposition of this one sentence, this books expands and unravels the context in which the ultimate identity of good and evil is to be understood. $\$ 49.50$ cloth, $475 \mathrm{pp}$.

\section{CHINESE HISTORY}

\section{A Manual, Revised and Enlarged ⿷NDYMION WILKINSON}

The new edition of this indispensable guide to researching the history of China has been updated through January 2000. It discusses some 4,300 primary, secondary, and reference works, and the temporal coverage has been expanded to include the Republican period. $\$ 25.00$ paper (also available in cloth), $1200 \mathrm{pp}$.

\section{BECOMING APART}

National Power and Local Politics

in Toyama, 1868-1945

\section{MICHALL LEWIS}

Focusing on Toyama, Lewis explores the interplay of central and regional authorities, local and national perceptions of rights, and the emerging political practices in Toyama and Tokyo that became part of the new political culture following the Meiji Restoration. $\$ 45.00$ cloth. 4 maps, 39 figs. 375 pp.

\section{CIVILIZING CHENGDU}

Chinese Urban Reform, 1895-1937

\section{KRISTIN STAPLETON}

In this detailed case study of late Qing and Republican Chengdu, Stapleton shows how reformers permanently changed urban administration, the urban landscape, and urban life by promoting a new type of orderly and productive community in population centers. $\$ 40.00$ cloth, 25 figs. 3 maps, 350 pp.

\section{ZHOU ZUOREN AND AN ALTERNATIVE CHINESE RESPONSE TO MODERNITY}

\section{SUSAN DARUVALA}

An exploration of the issues of nation and modernity in China, this book focuses on the work of Zhou Zuoren and his alternative vision of the nation that emphasizes traditional aesthetic categories, the locality rather than the nation, and a literary history that values openness and individuality. $\$ 39.50$ cloth, $375 \mathrm{pp}$.

\section{POETRY AND PAINTING IN SONG CHINA}

The Subtle Art of Dissent

\section{ALFREDA MURCK}

By examining literary archetypes, the titles of paintings, contemporary inscriptions, and the historical context, Murck shows that certain paintings expressed strong political opinions and argues that this led to the growing respect of the educated elite for painting. $\$ 60.00$ cloth, 44 illus. 2 maps. 400 pp. 


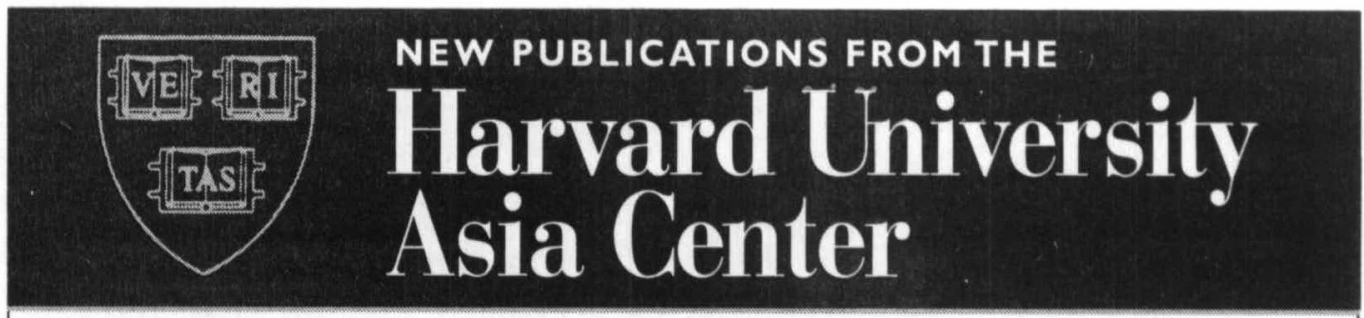

\section{BRANCHES OF HEAVEN}

A History of the Imperial

Clan of Sung China

JOHN W. CHAFEEE

In this study of the role of the imperial clan in the governance of Sung China, Chaffee analyzes its history, its political role, and the lifestyle of its members, particularly their residence patterns, marriages, and occupations. $\$ 45.00$ doth, 2 maps, 4 figs, 16 tables, 460 pp.

\section{PRAYER AND PLAY IN LATE TOKUGAWA JAPAN}

Asakusa Sensōji and Edo Society NAM-LIN HUR

Hur's reappraisal of prayer and play in Edo society provides a cultural critique of conventional scholarship on Tokugawa religion and shows how Edo commoners incorporated cultural politics into their daily lives through the pursuit of prayer and play. $\$ 40.00$ cloth, 13 figs, 5 tables, 318 pp.

\section{COLONIAL MODERNITY IN KOREA} GI-WOOK SHIN AND MICHAEL ROBINSON, EDITORS

The twelve chapters in this volume address the subjects of colonial domination through the legal system, the corporatist Japanese state in Korea, the growth of communications networks and an industrial workforce, and new forms of identity during the colonial period. $\$ 49.50$ cloth II tables, 7 figs, 2 maps, 475 pp.

\section{CULTURE AND THE STATE IN LATE CHOSON KOREA}

\section{JANYUN KIM KABOUSN AND} MARTINA DEUCHLER, EDITORS

The six chapters in this volume investigate the shifting boundaries between the Chöson state and the adherents of Confucianism, Buddhism, Christianity, and popular religion from the late 16 th through the 19th centuries. $\$ 40.00$ cloth, 2 tables, $316 \mathrm{pp}$.

Available on $\mathrm{CD}$
Now Available in Poperback

\section{THE HARVARD KOREAN STUDIES BIBLIOGRAPHY}

80,000 References on Korea

COMPILED BY FRANK MOFFMANN, WITH MATTHEW J. CHRISTENSEN

AND KIRK W. LARSEN

The Harvard Korean Studies Bibliography lists 50,000 articles, 17,000 books, 4,000 chapters in books, 7,000 dissertations, and 4,000 reviews. The software included with the $C D$ allows searches by author, title, subject, or date of publication. The $C D$ can be run with either Macintosh $®$ or Windows ${ }^{\circledR}$ systems. $\$ 25.00$ (available as CD only, not a book)

\section{Now Available in Paperback}

\section{THE ALIENATED ACADEMY}

Culture and Politics in Republican China,

1919-1937

\section{WEN-HSIN YEH}

Drawing on letters, essays, yearbooks, university records, and archives, Yeh explores the world of college youth between the two wars and examines the movement of education away from classical studies toward modern institutions with diverse programs. $\$ 19.95$ paperback, 5 tables, 7 figs, 450 pp

\section{WAR AND NATIONAL REINVENTION}

Japan in the GreatWar, 1914-1919

\section{FREDERICK R. DICKINSON}

Dickinson links the focus of studies of the nation on language, culture, and race and the emphasis of diplomatic history on international developments to show how political, diplomatic, and cultural concerns together shaped national identity in early 20th-century Japan. $\$ 19.95$ paperback. 21 figs. 390 pp.

\section{DISTRIBUTED BY \\ HARVARD UNIVERSITY PRESS}




\section{ASIAN INTERACTIONS AND COMPARISONS SERIES}

\section{Now AVAILABLE FROM AAS!}

The first two books of this new series, published jointly by the AAS and the University of Hawaii Press, can now be ordered directly from the AAS office.

The I Ching in Tokugawa Thought and Culture, by Wai-ming Mg This study uses the I Ching (Book of Changes) to analyze the role of Chinese learning in the development of thought and culture in Tokugawa Japan (1603-1868).

"This is an ambitious and impressive piece of scholarship. Mg deals with a subject that is rarely taken up in Japenese scholarship and virtually untouched in Western writing about Japan. The result is a landmark study that should provide the basis for publications for years to come."

Marius B. Jansen, Princeton University

Paper Edition, ISBM: 0-8248-2242-0. List Price: \$31.95. (Member Price: \$25.50)

Sovereign Rights and Territorial Space in Sino-Japanese Relations, by Unryu Suganuma

This volume is an investigation of the highly topical issues involved in the 1996 confrontation between China and Japan over the sovereignty of the Diaoyu/Senkaku Islands, a small group of uninhabited islets north of Taiwan. This volume is the fullest scholarly treatment that the contested issue has received to date in any language.

Cloth Edition, ISBN: 0-8248-2159-9. List Price: $\$ 50$. (Member Price: $\$ 40$ )

ASSOCIATIOM FOR ASIAM STUDIES

1021 East Huron Street

Ann Arbor, MI 48104

Phone: 734-665-2490; Fax: 734-665-3801

bookorder@aasianst.org 


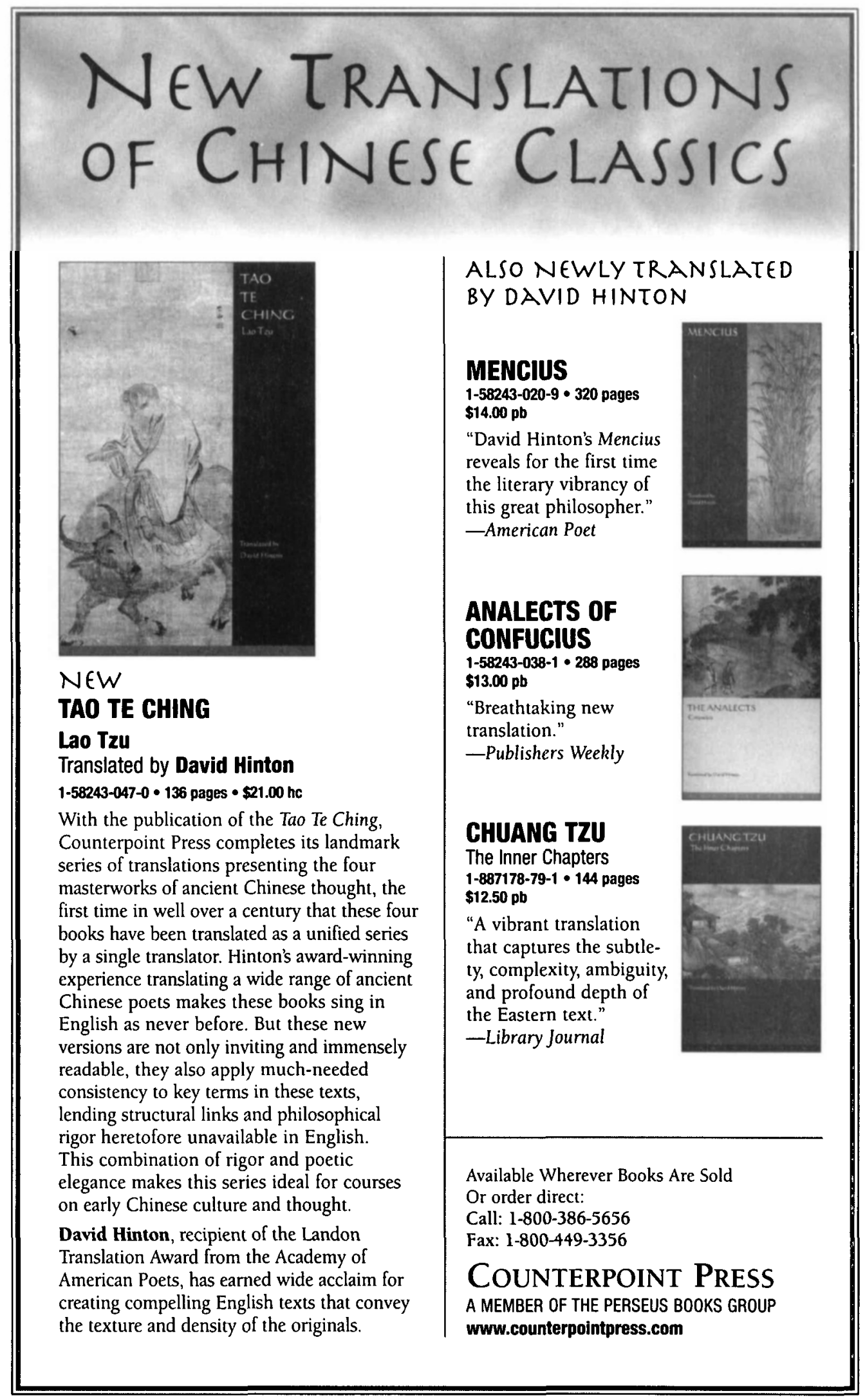




\section{New and Noteworthy}

\section{Internal Labour Markets in Japan \\ Kenn N. Ariga, Giorgio Brunello, and Yasushi Ohkusa}

Internal Labour Markets in Japan analyzes the employment practices of individual firms in Japan, including wages, training, promotion, transfers and turnovers across firms. It provides a comprehensive account of the Japanese ILM, and provides theoretical models that are applied to empirical analysis using the data on Japanese firms. It also includes a detailed case study of a large Japanese firm, and contains a section that deals with the most recent changes in Japanese ILM after the "bubble" economy boom and subsequent recession. An international comparative perspective is used throughout.

0-521-64240-X Hardback \$69.95

\section{The Cinema of Hong Kong}

History, Arts, Identity

Poshek Fu and David Desser, Editors

Providing an overview of major directors, genres and stars, from its origins to the present, this volume examines Hong Kong cinema in transnational, historical, and artistic contexts. Individual essays focus on Hong Kong cinema before and during World War II; the cinema of the turbulent 1960s; its rise to world prominence in the 1970 s and its reception in the United States, and the revival of Cantonese cinema, among other topics.

0-521-77235-4 Hardback \$64.95

\section{Prostitution and Sexuality in Shanghai \\ A Social History (1849-1949) \\ Christian Menriot}

Translated by Noel Castelino

Shanghai's nightlife, from the mid-nineteenth century until the victory of the Communist Party in 1949, was dominated by the world of prostitution. Henriot portrays the Chinese sex trade, from the sophisticated life of the courtesan, to the common life of street prostitution. He examines the extent to which these worlds were integral to Chinese social life, commercial trends, and Chinese mores and sexuality. He draws a picture of a sector that was sensitive to economic and social change, and thus a good reflection of Shanghai's changing social structure, societal attitudes, and commercial development.

0-521-57165-0 Hardback $\$ 85.00$

\section{Technology, Learning and Innovation}

Experiences of Newly Industrializing Economies

\section{Linsu Kim and Richard R. Nelson, Editors}

This volume presents ten original essays and four commentaries contributed by leading scholars in technology and innovation that discuss how newly industrializing countries (NICs), particularly those in East Asia, have transformed themselves from technologically backward and poor to relatively modern and affluent economies over the past thirty years. They provide interesting theoretical perspectives and the insightful understanding of the process of technological progress at both the macro and micro levels in these countries.

$\begin{array}{lll}0-521-77003-3 & \text { Hardback } & \$ 64.95 \\ 0-521-77987-1 & \text { Paperback } & \$ 22.95\end{array}$

\section{Music from the Tang Court 7}

\section{Some Ancient Connections Explored}

\section{Laurence Picken and Noël J. Nickson, Editors}

During the two centuries before 841 the Japanese Court borrowed a large amount of secular entertainment music from China. "Tang Music" (Togaku) survives in Japan in a substantial body of manuscripts, but is transformed in character in contemporary performance. This edition transcribes and comments on the music as it survives in its earliest sources and this process has revealed surprising evidence, presented in this seventh volume, for ancient interconnections in music of different cultures.
0-521-78084-5 Hardback $\$ 90.00$ 


\section{from Cambridge}

\section{The Global World of Indian Merchants, 1750-1947 \\ Traders of Sind from Bukhara to Panama \\ Claude Markovits}

Claude Markovits' book charts the development of two merchant communities in the province of Sind from the precolonial period, through colonial conquest and up to independence. Based on previously neglected archival sources, it describes how the communities came to control trading networks throughout the world, throwing light on the nature of these diasporas from South Asia in their interaction with the global economy. This is a sophisticated and accessible book that will appeal to students of South Asia, as well as to colonial historians and economic historians.

Cambridge Studies in Indian History and Society 6

0-521-62285-9 Hardback \$64.95

\section{The Asian Financial Crisis and the Architecture of Global Finance Gregory W. Noble and John Ravenhill, Editors}

The financial crises across Asia in 1997-98 ignited fierce debate about domestic economic weaknesses and flaws in the international financial system. Some analysts blamed Asian governments for inadequate prudential supervision, widespread failures of corporate governance and even "crony capitalism." Others assailed the inherent instability of global financial markets and what they considered to be hasty and illconceived liberalization taken at the behest of western-dominated international financial institutions. In this volume a distinguished group of political scientists, economists, and practitioners examines the political and economic causes and consequences of the crisis.

\section{Cambridge Asia-Pacific Studies}

$\begin{array}{lll}0-521-79091-3 & \text { Hardback } & \$ 64.95 \\ 0-521-79422-6 & \text { Paperback } & \$ 22.95\end{array}$

\section{The Morphology of Chinese}

A Linguistic and Cognitive Approach

Jerome L. Packard

This book aims to dispel the myth that Chinese "doesn't have words" but instead "has characters." Jerome Packard challenges the common belief that Chinese has no morphology, demonstrating how analysis of Chinese word formation enhances our understanding of word universals in natural language. His book describes the intimate relationship between words and their components and offers new insights into their evolution. Models are offered for how Chinese words are stored in the mental lexicon and processed in natural speech.

0-521-77112-9 Hardback \$64.95

\section{Fu Ssu-nien}

A Life in Chinese History and Politics

Fan-sen Wang

Fu Ssu-nien, a scholar, activist, and social critic, was one of the most influential intellectual figures in twentieth-century China. This biography offers the first in-depth examination of his role in intellectual and educational development in modern China. Wang Fan-sen follows Fu's early career as a student activist, his efforts to establish a "modern" historical discipline in China, and his legacy as a founder of modern academe in China. This book, incorporating unpublished material from Fu's personal archives, fills a major gap in the cultural and intellectual history of modern China.

Cambridge Studies in Chinese History, Literature and Institutions

0-521-48051-5 Hardback \$59.95

Available in bookstores or from 


\title{
"India's Prisoner"
}

\section{A Biography of Edward John Thompson, 1886-1946}

\author{
Mary Lago
}

\section{"Thompson is important, far more important I now know after reading the biography than I ever imagined him to be."-Clinton B. Seely}

Edward John Thompson-novelist, poet, journalist, and historian of India-was a liberal advocate for Indian culture and political self-determination at a time when Indian affairs were of little general interest in England. As a friend of Nehru, Gandhi, and other Congress Party leaders, he was an excellent channel for interpreting India to England and England to India. This important biography casts considerable light on Thompson and his struggles with his religion and his relationship with India.

January, 392 pages, 35 illustrations, $\$ 39.95$

\section{UNIVERSITY OF MISSOURI PRESS}

\section{LeMone Boulevard Columbia, MO 65201 $1-800-828-1894$ \\ http://www.system.missouri.edu/upress}

\section{MUSEUM QUALITY EXHIBITS}

"MY LIFE IS MY MESSAGE"-40 panels $(2 \cdot \times 4)$ of photographs with captions on the life of Mahatma Gandhi.

"INDIA-THE PEOPLE AND THEIR LAND"-more than 100 color photographs taken over 40 years by Beatrice Pitney Lamb.

"BEAUTY IN STONE"-Hindu, Buddhist, and Islamic architec-

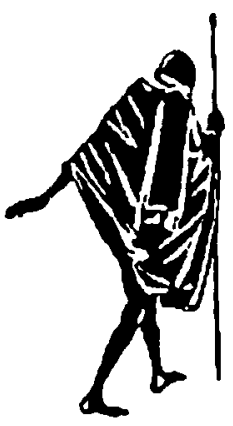
ture of india, color photographs by Beatrice Pitney Lamb.

Also smaller portable exhibit (sent by mail), video-cassettes (including biographical documentaries of Gandhi), and other resources available for loan.

Undergraduate-level CORRESPONDENCE COURSE on Gandhi (study materials from the Gujarat Vidyapith University in India, founded in 1920).

\author{
THE GANDHI MEMORIAL CENTER \\ P.O. BOX 9515 \\ Washington, D.C. 20016 \\ Phone: (301) 229-3871 \\ Website: www.self-rev-gandhi.org \\ Email: gandhimc@erols.com
}




\section{THE ORIGINS AND DEVELOPMENT OF PURE LAND BUDDHISM}

A Study and Translation of Gyonen's lodo Homon Genrusho

Edited by MARK L. BLUM

This book offers a critical look at the thought and impact of the late 13th-century Buddhist historian Gyonen and the emergent Pure Land school of Buddhism founded by Honen. Blum also provides a fully annotated translation of Gyonen's Jodo homon genrusho, the first history of Pure Land Buddhism.

November 2000336 pp.; 6 halliones 545.00

\section{WORKING A DEMOCRATIC CONSTITUTION}

The Indion Experience

GRANVILLE AUSTIN

Working a Democratic Constitution, Austin's magnum opus, tells the very human story of how the social, political, and day-to-day realities of the Indian people have been reflected in and directed the course of constitutional reforms since 1950 .

2000792 pp. $\$ 49.95$

\section{SINGING TO THE GODDESS}

Poems to Koli and Umo from Bengal RACHEL FELL MCDERMOTT

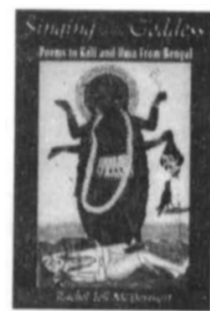

This vibrant collection presents 145 brief Bengali lyric poems dedicated to the Hindu goddesses Kali and Uma. McDermott's lively translations of these lyrics evoke the passion and devotion of the followers of Kali and Uma and shed light on the history and

practice of goddess worship.

2000304 pp.; 8 halfiones paper $\$ 19.95$ toth $\$ 45.00$

\section{Forthcoming!}

\section{THE POLITICIZATION OF ISLAM}

Reconstructing Identity, State, Faith, and Community in the Lote OHomon Stole

\section{KEMAL H. KARPAT}

Combining international and domestic perspectives, this book analyzes the transformation of the Ottoman Empire over the nineteenth and twentieth centuries. It views privatization of state lands and the increase of domestic and foreign trade as key factors in the rise of a Muslim middle class.

(Studies in Middle Eastern History)

December $2000640 \mathrm{pp} . \$ 55.00$

\section{ECHOES OF HISTORY}

\section{Noxi Music in Modern Chino} HELEN REES

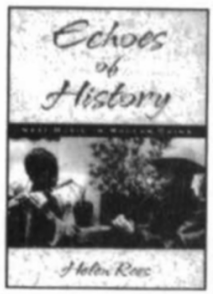

Drawing on extensive fieldwork and documentary research in China, this book chronicles the musical history of Lijiang County in China's southern Yunnan Province. Rees focuses on Donging music, repertoire borrowed from China's Han ethnic majority by the indigenous Naxi inhabitants of Lijiang County.

2000304 pp.; 12 holftones, 15 linecuts, $C 0$ paper $\$ 35.00$ dloth $\$ 65.00$

\section{CLASSIC ASIAN PHILOSOPHY}

A Guide to the Essential Texts JOEL J. KUPPERMAN

This book is designed to give someone new to Asian philosophy a clear sense of its most foundational and widely available texts, ranging from the Upanishads and the Bhagavad Gita through Confucius to Zen. It presents philosophies that are at the roots of the cultures of India, China, Korea, and Japan, as well as other countries of south and east Asia. Hovember $2000208 \mathrm{pp}$. poper $\$ 18.95$ cloth $\$ 45.00$

\section{AN ANTHOLOGY OF PHILOSOPHY IN PERSIA Volume II Edited by SEYYED HOSSEIN NASR and MEHDI AMINRAZAVI}

This is the second volume in a projected fivevolume work covering the full expanse of Persian philosophical thought from the Zoroastrianism of the pre-Christian era up to the present day. Volume II is devoted entirely to the work of the Isma'ili and HermeticPythagorean philosophers.

2000384 pp. $\$ 75.00$

\section{BEYOND HINDU AND MUSLIM}

Multiple Identity in Narratives from Village Indio PETER GOTTSCHALK

Foreword by WENDY DONIGER

Questioning the conventional depiction of India as a nation divided between religious communities, Gottschalk shows that individuals living in India have multiple identities, some of which cut across religious boundaries. The stories narrated by villagers living in the northern state of Bihar depict everyday social interactions that transcend the simple divide of Hindu and Muslim. 2000240 pp.; 3 mops $\& 16$ halfiones $\$ 35.00$
Prices are subject to change and apply only in the US. To order, or for more information, please call 1-800-451-7556. In Canada, call 1-800-387-8020. Visit our website ot $w w w .0 u p . c o m$

\section{OXFORD} UNIVERSITY PRESS 


\title{
The Association for Asian Studies, Inc.
}

\author{
1021 East Huron Street, Ann Arbor, MI 48104 USA
}

Officers of the Association. President-Peter Duus, Stanford University. Vice President-Charles Keyes, University of Washington. Past President-Susan L. ManN, University of California, Davis. Past-Past President-Wendy DonIGER, University of Chicago.

Board of Directors. President, Vice President, Past President, and Past-Past President, as listed above. Editor of the Journal of Asian Studies - ANN B. WALTNER, University of Minnesota. China and Inner Asia Council-RoBert Weller, Boston University. Northeast Asia Council-Kären Wigen, Duke University. South Asia Council-Sugata Bose, Tufts University. Southeast Asia Council-Belinda Aquino, University of Hawaii at Manoa. Council of Conferences-MAaILYN LeVINE, Lewis \& Clark State College. Program Committee-Ronald Heraing, Cornell University.

Staff of the Association. Executive Director-Michael Paschal. Comptroller-Carol J. Kelingos. Publications Manager-AnN W. Beard. Conference Manager-Karen F. Faicke. Membership Manager-JoanDewer. Publications CoordinatorMebsite Manager-JonATHAN WILSON. Fulfillment Coordinator-ANNe ARIZALA. Registration Coordinator-LINDA SMITH. Accounts Receivable-VIenna Gordon. Office Assistant-KaApINa QuinnelL.

Sponsoring Institutions. University of Michigan and University of Minnesota.

\section{EDITORIAL AND SUBSCRIPTION INFORMATION}

The Journal of Asian Studies (ISSN 0021-9118), known until September 1956 as the Far Eastern Quarterly, is published by the Association for Asian Studies (formerly the Far Eastern Association) in February, May, August, and November. The annual subscription rate for the Journa/is $\$ 70$ for U.S. addresses and $\$ 80$ for non-U.S. addresses, with postage included for delivery by Periodicals Postal Class. (The subscriber has the option of paying extra for delivery by U.S. First Class or Foreign Airmail.) Single issues published after February 1974 are available from the Secretariat of the Association. Issues published prior to 1958 may be purchased from A.M.S. Reprints, 56 East 13th Street, New York, NY 10003 USA. Bell \& Howell, 300 North Zeeb Road, Ann Arbor, MI 48106 USA offers all volumes on either microfilm or microfiche.

All correspondence regarding memberships, subscriptions, advertising, reprints, and similar issues should be addressed to the office of the Association for Asian Studies, 1021 East Huron Street, Ann Arbor, Michigan 48104 USA.

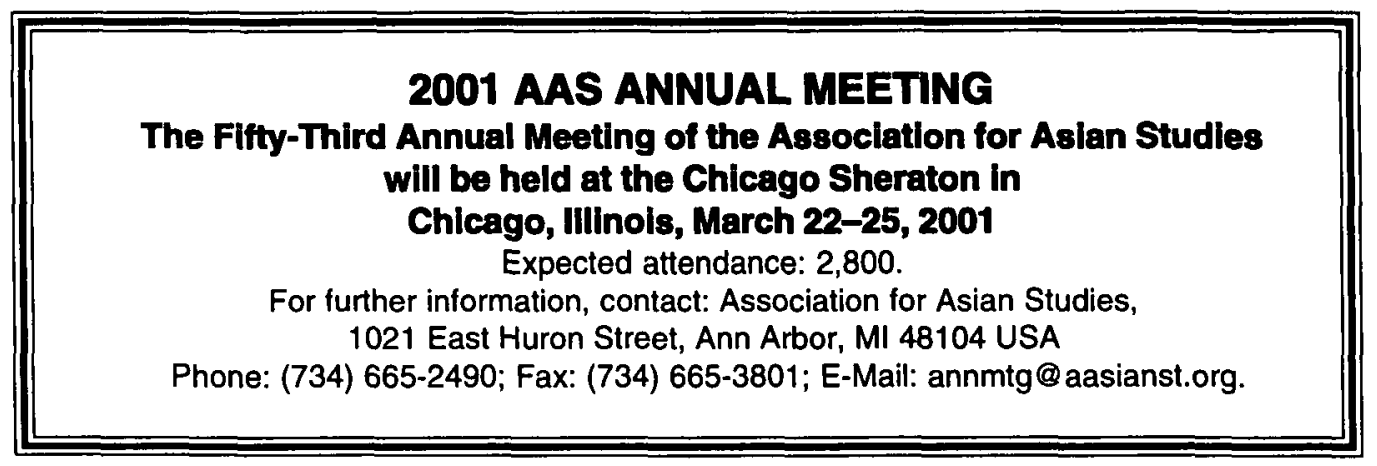


James Siegel

\section{The Rope of God}

With a New Preface and Two

Additional Chapters

Siegel traces the evolution in Islam, in the economy, and in the structure of the family to show how Aceh mobilized itself as a society from the time of the colonial war to the emergence of the republic.

paper $\$ 19.95$

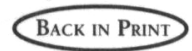

Edward LiPuma

\section{Encompassing Others}

The Magic of Modernity in Melanesia

This history of the encounter of capitalism, colonialism, and Christianity with Melanesian society have informed the study of modernity. cloth $\$ 49.50$

Louise EDWARDS AND Mina Roces, Editors Women in Asia Tradition, Modernity, and Globalisation

Women in Asia surveys the transformation in the status of women since 1970 in a Malaysia, China, Indonesia, Singapore, the Philippines, India, Taiwan, Vietnam, Hong Kong, Korea, Japan, and Burma.

paper $\$ 17.95$

Truong Buy Lam

\section{Colonialism}

\section{Experienced}

Vietnamese Writings on

Colonialism, 1900-1931

A collection of political literature that marked the transition between dominant Confucian and nascent Western worldviews in Vietnam.

cloth $\$ 69.50$, paper $\$ 19.95$ challenges the main concepts that

\section{A. L. BeCKer}

\section{Beyond Translation} Essays on a Modern Philology

Becker's study of Burmese, Javanese, and Malay texts express the subtleties of cultural identity. paper \$24.95 Now in Paper

Jan Breman, Arvind Das, And Ravi Agarwal

\section{Down and Out}

Labouring Under

Global Capitalism

This richly illustrated and unique study portrays the working class in India and their struggle to survive.

Distributed for Amsterdam

University Press

cloth $\$ 25.00$

\section{Noma Hiroshi}

\section{"Dark Pictures" and} Other Stories

Iranslated and with an Afterword by James Raeside

Dark and haunting stories of young men whose universal desires and anxieties are overshadowed by memories of the brutality of war

Distributed for the Center for Japanese Studies, University of Michigan

cloth $\$ 32.95$, paper $\$ 15.95$

\section{TUNG YUeH}

\section{The Tower of Myriad}

\section{Mirrors}

Translated by Shuen-fu Lin and Larry J. Schulz

China's most outrageous characterthe magical Monkey who battles a hundred monsters-returns to the fray in this seventeenth-century sequel to the Buddhist novel Journey to the West.

Distributed for the Center for Chinese Studies, University of Michigan paper $\$ 20.00$

\section{AnNeliese Riles \\ The Network Inside Out}

This study of "networks" and other artifacts of institutional life sheds light on knowledge and legality in today's world.

cloth $\$ 49.50$

David Y. H. WU AND

Tan Chee-beng, Editors

Changing Chinese Foodways in Asia

The contributors use the lens of food to address recent theories in social science concerning cultural identity, ethnicity, boundary formation,

consumerism, globalization, and the invention of local cuisine in the context of rapid culture change.

Distributed for The Chinese University Press

cloth $\$ 40.50$

\section{HARRIET WhitehEad \\ Food Rules}

Hunting, Sharing, and Tabooing Game in Papua New Guinea

Whitehead explores the significance of the food rules of two tiny

Seltaman villages, giving us both a profoundly insightful account of

Papuan village life and a new way of understanding culture.

cloth $\$ 54.50$

Yu Feng

\section{A Learner's Handbook of Modern Chinese Written Expressions}

A concise and practical bilingual handbook for students of advanced Chinese.

Distributed for The Chinese University Press paper $\$ 23.00$

Credit card buyers may order by phone (734/764-4392) or by fax (800/876-1922).

www.press.umich.edu
The University of Michigan Press Dept. BX

Ann Arbor, Michigan 48106-1104 
SUSAN MANN

Presidential Address:

Myths of Asian Womanhood

AMY GUROWITZ

Migrant Rights and Activism in Malaysia:

Opportunities and Constraints

BRYNA GOODMAN

Improvisations on a Semicolonial Theme, or,

How to read Multiethnic Participation

in the 1893 Shanghai Jubilee

\section{JOSHUA A. FOGEL}

"Shanghai Japan": The Japanese Residents'

Association of Shanghai

ANDRE SCHMID

Colonialism and the "Korea Problem" in the Historiography of Modern Japan: A Review Article 